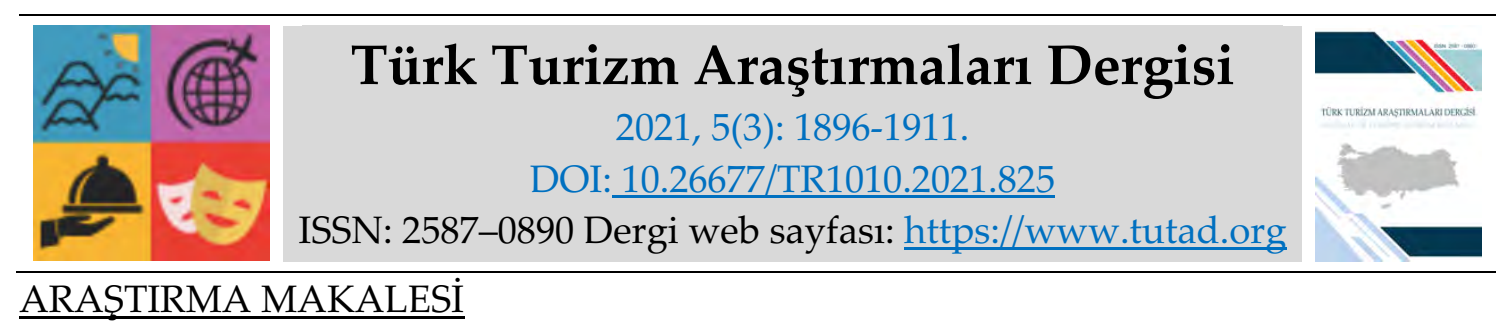

\title{
Pandemi Döneminde TaTuTa Çiftliklerinin Uyguladığı Stratejiler
}

Doç. Dr. Aliye AKIN, Bolu Abant İzzet Baysal Üniversitesi, Turizm Fakültesi, Bolu, e-posta: aliye.akin@ibu.edu.tr ORCID: https://orcid.org/0000-0001-8589-7547

Öğr. Gör. Adnan AKIN, Bolu Abant İzzet Baysal Üniversitesi, Bolu Meslek Yüksekokulu, Bolu, e-posta: adnan.akin@ibu.edu.tr

ORCID: https://orcid.org/0000-0002-7023-1678

Mehtap BAŞ, Yüksek Lisans Öğrencisi, Gaziantep Üniversitesi, Sosyal Bilimler Enstitüsü, Gaziantep, e-posta: mehtap 811@hotmail.com

ORCID: https://orcid.org/0000-0001-9073-0258

Dr. Halil İbrahim KARAKAN, İstanbul Galata Üniversitesi, Sanat ve Sosyal Bilimler Fakültesi, İstanbul, e-posta: hikarakan@gmail.com

ORCID: https://orcid.org/0000-0003-3335-0923

Öz

TaTuTa projesi (Tarım Turizm Takas), ekolojik tarım ile geçimini sağlayan çiftçi ailelerine gönüllü olarak finans, işgücü ve bilgi gibi konularda destek sağlamak amaciyla kurulmuştur. Proje, ziyaretçilere doğa dostu tarımsal üretim alanlarında yaşama ve öğrenme fırsatı sunarak ekolojik tarım uygulamaları hakkında farkındalık oluşturmayı hedeflemektedir. Bu doğrultuda çiftlik sahipleri, tarımsal faaliyetlerde yer almak isteyen yerli ve yabancı turistleri ağıllayarak tarım turizmi imkânı sunmakta, turistler de bu çiftliklerde tarımsal üretime emek ve sermaye olarak katkı sağlamaktadır. Çalışmanın amacı, TaTuTa ekolojik çiftliklerinin, Covid-19 pandemisinin yarattı̆̆ krizi fırsata dönüştürebilme kabiliyetlerini belirlemek ve pandemi döneminde uyguladıkları stratejileri tespit etmektir. Bu kapsamda Türkiye'de faaliyet gösteren toplam 75 TaTuTa çiftliğinden 21 tanesinin yöneticilerine online görüşme formu gönderilerek veriler toplanmıştır. Buna göre, örneklem kapsamındaki çiftliklerden 11 tanesinin kriz ortamında risk almaktan kaçındığı ve herhangi bir strateji geliştirmediği, tarım turizmi faaliyetlerini ve ziyaretçi kabulünü durdurduğu saptanmıştır. Pandemiyi fırsata dönüştürmek isteyen ve risk alan 10 çiftliğin ise ürün genişletme, ürün farklılaştırma, tutundurma ve odaklanma gibi stratejiler geliştirerek krizi fırsata çevirmeyi başardıkları tespit edilmiştir.

Anahtar Kelimeler: Tarım, Turizm, Ekoloji, TaTuTa Çiftlikleri.

Makale Gönderme Tarihi: 20.05.2021

Makale Kabul Tarihi: 03.09.2021

\section{Önerilen Atıf:}

Akın, A., Akın, A., Baş, M. ve Karakan, H. İ. (2021). Pandemi Döneminde TaTuTa Çiftliklerinin Uyguladığı Stratejiler, Türk Turizm Araştırmaları Dergisi, 5(3): 1896-1911.

(C) 2021 Türk Turizm Araştırmaları Dergisi. 


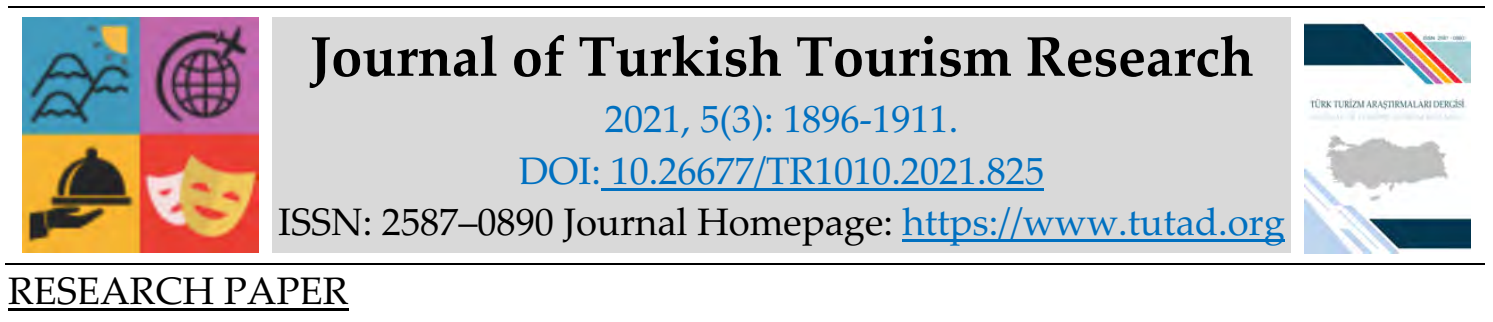

\title{
Strategies Implemented by Tatuta Farms During the Pandemic Period
}

Associate Prof. Dr. Aliye AKIN, Bolu Abant İzzet Baysal University, Faculty of Tourism, Bolu, email: aliye.akin@ibu.edu.tr

ORCID: https://orcid.org/0000-0001-8589-7547

Lecturer Adnan AKIN, Bolu Abant İzzet Baysal University, Bolu Vocational School, Bolu, e-mail: adnan.akin@ibu.edu.tr

ORCID: https://orcid.org/0000-0002-7023-1678

Mehtap BAŞ, MSc. Student, Gaziantep University, Social Sciences Institute, Gaziantep, e-mail: mehtap 811@hotmail.com

ORCID: https://orcid.org/0000-0001-9073-0258

Dr. Halil İbrahim KARAKAN, İstanbul Galata University, Faculty of Arts and Social Sciences, İstanbul, e-mail: hikarakan@gmail.com

ORCID: https://orcid.org/0000-0003-3335-0923

\begin{abstract}
The TaTuTa project (Agricultural Tourism Barter) was established to voluntarily provide support to farmers' families, who make a living with ecological agriculture, in matters such as finance, labor and information. The project aims to raise awareness about ecological farming practices by providing visitors with the opportunity to live and learn in nature-friendly agricultural production areas. In this direction, farm owners offer agricultural tourism opportunities by hosting local and foreign tourists who want to take part in agricultural activities, and tourists contribute to agricultural production in these farms as labor and capital. The aim of the study is to determine the ability of TaTuTa ecological farms to turn the crisis created by the Covid-19 pandemic into an opportunity and to determine the strategies they implement during the pandemic period.In this context, sending a total of 75 managers TaTuTa online interview form the data was collected 21 of them from the farm in Turkey. Accordingly, it was determined that 11 of the farms in the sample avoided taking risks in the crisis environment, did not develop any strategy, and stopped agricultural tourism activities and visitor acceptance. It has been determined that 10 farms that want to turn the pandemic into an opportunity and take risks have succeeded in turning the crisis into an opportunity by developing strategies such as product expansion, product differentiation, promotion and focus.
\end{abstract}

Keywords: Agriculture, Tourism, Ecology, TaTuTa Farms.

Received: 20.05.2021

Accepted: 03.09.2021

Suggested Citation:

Akın, A., Akın, A., Baş, M. and Karakan, H. İ. (2021). Strategies Implemented by Tatuta Farms during the Pandemic Period, Journal of Turkish Tourism Research, 5(3): 1896-1911.

(c) 2021 Türk Turizm Araştırmaları Dergisi. 


\section{Gíriş}

Turizm sektörü küresel ekonominin en hızlı büyüyen sektörlerinden birisidir. Bu doğrultuda dünya genelinde yarattığı ekonomik, sosyal, siyasal ve kültürel etkileri ile hizmet sektörü içinde önemli bir paya sahiptir (Çeken, 2004: 10). Söz konusu özellikleri itibariyle de turizm sektörü, inşaat, ulaştırma, tarım, sanayi, sağlık, eğitim, teknoloji gibi çok sayıda sektörle ilişki içerisindedir. Özelikle turizm sektörünün tarım sektörü ile sürekli ve yoğun bir ilişki içerinde olduğu bilinmektedir. Doğal kaynaklar, bitki örtüsü, iklim, yer şekilleri, toprak yapısı ve çeşitliliği açısından Türkiye'nin hem tarım hem de turizm potansiyelinin yüksek olduğunu söylemek mümkündür. Bu durum ülkede tarımsal üretim ve alternatif turizm çeşitliliğine olanak sağlamaktadır.

Tarım ve turizm sektörleri, günümüzde birbirlerini tamamlayıcı özellikler göstermektedir. Kalabalık, stresli ortamlarda ve yoğun çalışma temposunda olan insanlar, huzur bulmak, doğa ve toprak ile iç içe olmak amacıyla tarımsal faaliyetlerin sunulduğu bölgelere yönelmektedir. Bu durum tarım ve turizm sektörlerini birleştirerek tarım turizmi (agro turizm) faaliyetlerini ortaya çıkarmaktadır. Böylelikle tarım turizmine katılan insanlar doğrudan tarımsal etkinliklerin içinde yer alarak farklı bir turizm deneyimi yaşamaktadır. Nitekim bu durum iki sektöre de ekonomik girdi sağlamaktadır (Civelek, 2013: 1-2).

3 Mart 2020 itibari ile Dünya Sağlık Örgütü tarafından pandemi ilan edilen viral hastalık Covid19, hayatın her alanını ve tüm sektörleri etkisi altına almıştır. Küresel bir pandemi haline gelen Covid-19, sağlık, ekonomik, sosyal, politik, etik ve ahlaki bazı sonuçlara yol açmıştır. Ülkelerin pandemiye karşı hazır olmaması, hastalığın bulaşma hızının yüksek olması, önlemlerin alınmasında geç kalınması gibi faktörler insanların doğal çevrede bireysel faaliyetlere yönelmesine neden olmuştur (Vanderweele vd., 2020). Dolayısıyla, geçmişte uluslararası düzeyde kitle turizm faaliyetlerine katılan çok sayıda insanın pandeminin etkisiyle özellikle kırsal alanlardaki tarımsal faaliyetlerde yer almak amacıyla farklı destinasyonlara seyahat ettiği görülmektedir.

Günümüzde özellikle çevre bilinci olan insanlar, sektörlerin ve işletmelerin faaliyetlerini gerçekleştirirken çevreye verdiği zararları dikkate almaktadır (Civelek vd., 2013: 23). Turizm faaliyetlerinin de çevreyi olumsuz etkilediğinin farkında olan turistler, özellikle eko turizm, tarım turizmi gibi daha çevre dostu turizm faaliyetlerine yönelmektedir. Söz konusu turistler ziyaret ettikleri destinasyonlarda yerel halkla iç içe olmayı, yerel halkın faaliyetlerinde yer almayı ve yöre ekonomisine katkıda bulunmayı arzulamaktadır (Mason, 2004: 14). Dolayısıyla pasif turizm anlayışının yerini aktif turizm türünün aldığı söylenebilir. Bu kapsamda turistler, turistik faaliyetlerin doğrudan içinde yer almak istemektedir. Tarım turizmi, ifade edilen faaliyetlere uygun bir örnek olarak gösterilebilir. Tarım turizmi doğrudan tarımsal çevreye, tarım ürünlerine ve ürünleri ekip, biçmeye aynı zamanda tarım alanlarındaki konaklamalara bağlı turizm şeklidir (Sharpley ve Sharpley, 1997: 9). Daha geniş bir ifadeyle "tarım turizmi temel olarak küçük çiftlikler olmak üzere, çiftçilere ek gelir sağlamak amacıyla bă̆, bahçe, tarla, ahır, ağıl, kümes vb. tarımsal üretim alanları ile küçük ölçekli ve geleneksel gıda işleme tesisleri gibi faaliyet alanların ziyaret etmek, günlük işlerine katılmak, çiftlik evinde gecelemek, gezinmek, eğlenmek, alışveriş yapmak ve bazen de eğitim almak gibi aktivitelerin bir veya birkaçını kapsayan bir turizm şeklidir" (Karakaya, 2017: 13-14). Tarım turizmi, sosyal anlamda dinlendirici, tedavi edici, çevresel anlamda eğitici özellikler içeren zirai, ekolojik ve kültürel ürünlerin bileşiminden meydana gelmektedir (Çıkın vd., 2009: 5). Tarım turizmi, tarımda çeşitlilik sağlanmasında, kırsal alanda iş olanaklarının arttırılmasında, tarımsal ürünlerin tanıtım ve pazarlanmasında önemli rol oynamaktadır. Bununla birlikte, yerli-yabancı ziyaretçilerle yerel halk arasında sosyo-kültürel ilişkinin kurulmasında da fayda sağlamaktadır (Gökalp ve Yazgan, 2013: 26). 
Tarım işletmelerine turizm amacıyla gelen ziyaretçilerin artması, işletmelerin devamlılı̆̆ını sağlamakta ve bölge/yöre ekonomisini de canlandırmaktadır. Ürün pazarlarındaki fiyat dalgalanmaları bu şekilde dengelenerek atlatılabilmektedir. Tarım turizmi, işletmede üretilen tarım ürünlerinin hem turizm faaliyetlerine girdi teşkil edecek biçimde kullanılmasına hem de ziyaretçilere satılmasına imkân vermektedir (Gündüz, 2004). Bu amaç kapsamında, Türkiye'nin farklı bölgelerinde ekolojik çiftlikler ve tarım işletmeleri kurulmuştur. Tarım turizmi açısından faaliyet gösteren bu çiftlikler proje kapsamında desteklenmekte ve geliştirilmeye çalışılmaktadır. Bu projelerden biri de TaTuTa projesidir.

Türkiye'deki eko turizm çiftlikleri, "Ekolojik Çiftliklerde Tarım Turizmi ve Gönüllü Bilgi, Tecrübe Takası" olarak bilinen ve kısa adı "TaTuTa" (Tarım-Turizm-Takas) olan proje ile faaliyetlerini sürdürmektedir. Proje, 2002 yılında başlamış ve 2004 yılında Buğday Ekolojik Yaşamı Destekleme Derneği'nin desteği ile Türkiye'nin birçok bölgesinde uygulamaya geçmiştir. Projenin başlangıç aşamasında özellikle altyapının oluşturulması amacıyla Küresel Çevre Fonu, Birleşmiş Milletler Kalkınma Programı, Küçük Destek Programı fonları kullanılmıştır (TaTuTa/WWOOF Türkiye, 2021). TaTuTa projesi, dünya çapında yaklaşık 100 ülkede, 11 binin üzerinde ekolojik çiftliğin üye olduğu WWOOF (World Wide Opportunities on Organic Farms / Organik Çiftliklerde Uluslararası Fırsatlar) ağının da Türkiye temsilcisidir. WWOOF, İngiltere' de 1971 yılında başlayan, kültürel ve eğitsel deneyimleri etkinleştirmek amacıyla gönüllüleri ekolojik çiftliklere bağlayan, sürdürülebilir ve küresel bir topluluk oluşturmayı amaç edinen bir harekettir. TaTuTa projesi, Türkiye'de ekolojik tarımla geçinen çiftçilere gönüllü işgücü ve/veya bilgi desteği sağlamayı amaçlamaktadır. Bu yolla ekolojik tarımı teşvik etmeyi ve sürdürülebilirliği hedeflemektedir. Tarım turizmi işleyişinde ise, ekolojik üretim yöntemleri konusunda karşılıklı bilgi ve deneyim takasını gerçekleştirmek, kültürlerarası alışverişin sağlanmasına katkıda bulunmak amaçlanmaktadır. TaTuTa projesi kapsamında tarım turisti olmak isteyen bir ziyaretçi, çiftliği gönüllü ve konuk olarak ziyaret edebilmektedir. Gönüllü katılımda, katılımcılar işgücü, bilgi ve tecrübelerini içeren her türlü desteği gönüllü olarak TaTuTa projesine kayıtlı çiftliğe sağlayarak buralarda konaklama, yeme-içme ihtiyaçlarını karşılayabilmektedir. Konuk olarak katılım da ise, çiftlikte çalışma zorunluluğu bulunmadan konaklama ve alınan hizmetler karşılığında, belirlenmiş bir ücreti çiftlik sahibine vermek gerekmektedir (Gönülsüz, 2015). Gönüllü ve konuk olarak çiftliği ziyaret eden misafirlere, sosyal ve kültürel aktivitelere katılma, perma-kültür hakkında eğitimler, şifalı bitkiler atölyesi, doğa yapı atölyesi, doğa gözlemi, çocuk kampları ve zeytinyağı yapımından, doğal sabun ve deterjan yapımı gibi birçok etkinlik verilmektedir.

Günümüzde Türkiye'nin farklı bölgelerinde yer alan TaTuTa Projesi kapsamında faaliyet gösteren 75 ekolojik tarım turizm çiftliği bulunmaktadır. Çiftliklerden 39 tanesi Ege, 5 tanesi Akdeniz, 13 tanesi Karadeniz, 9 tanesi İç Anadolu ve 9 tanesi Doğu Anadolu Bölgesinde yer almaktadır (TaTuTa/WWOOF Türkiye, 2021). Tarım ve turizm arasında bir köprü niteliğinde olan TaTuta çiftlikleri hem gönüllü hem de konuk ağırlaması bakımından yerel halka, bölge kültürüne ve istihdama önemli katkılar sunmaktadır.

Çalışmada, Türkiye'deki TaTuTa çiftlik yöneticilerinin Covid-19 pandemi dönemindeki uygulamaları ve aldıkları önlemleri tespit etmek amaçlanmıştır. Çünkü pandemi döneminde söz konusu çiftliklere yönelik yerli ve yabancı turist talebinin artması, bölgenin ve destinasyonun ekonomik ve sosyo-kültürel açıdan gelişmesini de sağlayacaktır. Bu kapsamda tarım ve turizm sektörlerinin birleşmesinde önemli rol oynayan söz konusu çiftliklerin, kriz dönemini fırsata çevirip çevirmedikleri konusunda bilgi edinmek hedeflenmiştir. 


\section{LITERATÜR TARAMASI}

Ulusal ve uluslararası alan yazında birçok araştırmacı tarafından ekolojik çiftlikler ve tarım turizmi kapsamında çeşitli konu başlıklarını içeren çok sayıda çalışmanın olduğu görülmektedir. Bu doğrultuda, McIntosh ve Bonnemann (2006), WWOOF kapsamında yer alan çiftliklerde konaklayan ziyaretçilerin deneyimlerini ve çiftliklerde sunulan konaklama imkanları arasındaki farklılıkları tespit etmek amacıyla çalışma gerçekleştirmişlerdir. Buna göre, Yeni Zelanda'nın güney adasındaki kırsal bölgede bulunan WWOOF'a bağlı 12 çiftlik yöneticisi ve 22 ziyaretçi ile görüşmeler yapılmıştır. Çalışmanın sonucunda çiftliklerde sunulan konaklama olanaklarının birbirinden çok farklı olduğu saptanmıştır. Bununla birlikte ziyaretçilerin deneyimlerini, kırsallık, bilgi edinme, samimiyet unsurlarının etkilediği ortaya konmuştur.

Yılmaz (2008), alternatif turizm çeşidi olarak ve kırsal alanların değerlendirilmesi açısından ekolojik çiftliklerin rolünü belirlemek amacıyla bir çalışma gerçekleştirmiştir. Bu kapsamda Türkiye'nin farklı bölgelerinde yer alan iki ekolojik çiftliği SWOT analizi kapsamında değerlendirmiştir. Çalışmanın sonucunda, çiftliklerde tarım turizmi faaliyetlerinin yapıldı̆̆g, çiftliklerin ekolojik açıdan uygun olduğu, tarım turizmi faaliyetlerinin yerel halka iş imkânı sağladığı tespit edilmiştir.

Yang vd., (2010) Çin'de şehirleşme uğruna, ekim yapılabilecek tarım arazilerinin azaldığı ve çevresel kaynakların bozulmaya başladığı konusuna vurgu yapmak amacıyla bir çalışma yapmışlardır. Söz konusu olumsuz etkilerin ülkede tarım turizmi yatırımları ile azaltılabileceği tespit edilmiştir. Bu doğrultuda 2004-2008 yılları arasındaki büyük ölçekli tarım turizmi yatırımlarının performansları değerlendirilmiştir. Sonuçta, şehir merkezleri ve kırsal alanlar arasında tarımsal üretim ve turizm faaliyetlerinin birlikte gerçekleştirildiği bir model ortaya çıkarılmıştır.

Selvi ve Demirer (2012), TaTuTa Projesinin, amacına ne derece ulaştığını saptamak amacıyla bir örnek olay çalışması gerçekleştirmiştir. Bu doğrultuda, projenin, çiftlikte organik tarımın tanıtımında, yerel halkla gönüllü ve ziyaretçilerin sosyo kültürel açıdan kaynaşmasında etkili olduğu tespit edilmiştir. Ancak, çiftliğe gelen gönüllü ve ziyaretçi sayısının çok az olduğu ve bu yolla herhangi bir ek gelir yaratılamadığı, ürünlerin çiftlik dışına satışının yapılamadığı saptanmıştır. Ayrıca, projenin çiftlikteki nitelikli işgücü sorunun çözülmesinde katkısının olmadığı ortaya konmuştur. Sonuçta, TaTuTa projesinin ekolojik çiftliklerde henüz amacına tam olarak ulaşmadığ

Civelek (2013), yüksek lisans tez çalışmasında Muğla ve çevresindeki TaTuTa çiftliklerinin tarım turizmi potansiyelini ve uygulamalarını belirlemeyi amaçlamıştır. Bu kapsamda özellikle kırsal alanlarda yapılan tarım turizmi faaliyetlerinin yerel halka istihdam fırsatı sağladığı (özellikle kadın istihdamı) ve halkın ekonomik, sosyo kültürel gelişmelerine olumlu etki ettiği belirlenmiştir. Ayrıca, tarım turizminin Muğla yöresindeki alt yapı sorunun çözümlenmesinde etkili olduğu tespit edilmiştir.

Yamamotoa ve Engelstedb (2014), ABD'de WWOOF'a kayıtlı çiftliklerin yerel özelliklerini ve motivasyonlarını belirlemek amacıyla çalışma yapmışlardır. Çiftlik sahipleriyle görüşmeler yapılarak veriler toplanmıştır. Buna göre çiftlik sahipleri ile ziyaretçilerin motivasyon unsurlarının farklı olduğu saptanmıştır. Ayrıca, ziyaretçilerin çok sayıda çiftlik için ucuz işgücü potansiyeli yarattığı, ancak ziyaretçilerin konaklama beklentilerinin çok yüksek olduğu tespit edilmiştir. Mahaliyanaarachchi (2015) çalışmasında çiftliklerin, üretimde kullandıkları modern tekniklerin tarım turistleri için çok çekici olmadığını dile getirmiştir. Tarım turizmi çiftliklerinin sadece turizm hizmetlerini iyileştirme alanında teknik gelişmeyi kabul ettiklerini belirtmiştir. Ahmadova ve Akova (2016) TaTuTa projesi kapsamında faaliyet gösteren çiftliklerin işleyiş̧ini ve uygulamalarını değerlendirmek amacıyla 17 çiftlik yöneticisiyle görüşmeler yapmışlardır. Bu 
kapsamda, çiftliklerde üretilen ürünlerin misafirlere sunulduğu, 9 çiftliğin de bu ürünlerin satışını gerçekleştirdiği tespit edilmiştir.

Şimşek (2016), çalışmasında proje kapsamında faaliyet gösteren çiftliklerin, ziyaretçilere alternatif bir ekolojik yaşam fırsatı sunup sunmadığını belirlemeyi amaçlamıştır. Buna göre, Türkiye'nin farklı bölgelerinde faaliyet gösteren 10 tane TaTuTa çiftlik yöneticisiyle görüşmeler yapılmıştır. Çağdaş şehir yaşantısından, stresten ve yoğun iş temposundan bunalan insanların özellikle ekolojik faaliyetlerde yer almak için bu çiftlikleri daha fazla talep ettiği belirlenmiştir. Ayrıca, ziyaretçilerden ve üretilen ürünlerin satışından dolayı çiftliklerin ekonomik kazanç sağladığı saptanmıştır. Zengin ve Savgın (2016), ülkedeki çiftlik turizminin durumunu belirlemek amacıyla Datça Yarımadası'nda bulunan ekolojik tarım yapan ve turizm tabanlı faaliyetleri uygulayan çiftliklerle görüşmeler ve gözlemler yapmışlardır. Çalışmanın sonucunda, stresten ve kalabalık ortamlardan uzaklaşmak isteyen ziyaretçilerin çiftliklerde tarım turizmi kapsamında farklı aktiviteleri deneyimlemek istedikleri saptanmıştır. Ancak, çiftliklerde Turizm Bakanlığı'nın belirlediği konaklama kapasitesinin ve donanımının bulunmadığı, konuk ağırlamak isteyen çiftçi ailelerin çeşitli izin ve yasal prosedürle karşı karşıya kaldığı belirlenmiştir.

Şekerli (2018), İzmir' de faaliyet gösteren beş ekolojik çiftliğin uygulamalarını belirlemek amacıyla çalışma gerçekleştirmiştir. TaTuTa projesinin, iş gücü ihtiyacının karşılanmasında, sosyo kültürel etkileşimde, bilgi alışverişinin sağlanmasında, yerli tohumların yaygınlaştııılması ve üretilen organik ürünlerin satış ve pazarlanmasında projenin önemli katkı sağladığı saptanmıştır.

Deniz vd., (2018) proje kapsamında Çanakkale' de faaliyet gösteren üç çiftliğin faaliyetlerini tespit etmek amacıyla gözlem ve görüşme tekniği ile veriler toplamışlardır. Bu doğrultuda çiftliklerde yetiştirilen ürünlerin ziyaretçiler tarafından toplandığı ve bu ürünlerle çeşitli yemeklerin yine ziyaretçiler tarafından hazırlandığı gözlemlenmiştir.

Yapılan literatür taraması sonucunda TaTuTa çiftlikleri üzerine farklı amaçlar içeren çeşitli çalışmalar yapıldığı görülmektedir. Ancak ekolojik TaTuTa çiftliklerinin pandemi dönemlerinde krizi fırsata çevirme kabiliyetleri ve pandemi dönemlerinde uyguladukları stratejiler ile ilgili herhangi bir çalışmaya tarafımızca rastlanmamıştır. Bu bağlamda bu çalışmanın alanyazına katkı sağlayacağı düşünülmektedir.

\section{YÖNTEM}

Pandemi döneminde zorunlu kısıtlamalardan dolayı özellikle tarım ve turizm sektörünün önemi ortaya çıkmıştır. Bu dönemde insanlar izole olmak zorunda olduklarından kitle turizm faaliyetlerine katılmaktan kaçınmışlardır. Bu durumun ekolojik çiftliklere yönelik turizm talebini arttırdığı düşünülmektedir. Çalışmanın amacı, TaTuTa ekolojik çiftliklerinin, Covid-19 pandemisinin yarattı̆̆ krizi fırsata dönüştürebilme kabiliyetlerini belirlemek ve pandemi döneminde uyguladıkları stratejileri tespit etmektir.

Araştırmada nitel veri toplama yöntemlerinden görüşme tekniği kullanılmıştır. Bu amaçla oluşturulan görüşme formu için 2021/151 protokol no ile Bolu Abant İzzet Baysal Üniversitesi Sosyal Bilimlerde İnsan Araştırmaları birimine etik kurul onayı başvurusu yapılmıştır. Kurul 29.04.2021 tarihli ve 2021/04 sayılı toplantısında görüşme formunu incelemiş ve etik açıdan uygun bulmuştur.

TaTuTa çiftlik yöneticileri ile görüşmek amacıyla hazırlanan form, 2 bölüm ve toplamda 15 sorudan oluşmaktadır. İlk bölümde TaTuTa çiftliklerinin genel bilgilerine yönelik 4 adet soru 
bulunmaktadır. İkinci bölümde ise söz konusu çiftliklerin pandemi dönemindeki faaliyetlerini, yaşadıkları krizleri ve uyguladıkları stratejileri sorgulayan 11 adet soru bulunmaktadır.

Türkiye'de 2021 yılı itibarıyla farklı şehirlerde 75 adet TaTuTa çiftliği faaliyet göstermektedir. Dolayısıyla zaman ve maliyet tasarrufu sağlamak için görüşme formları çiftlik yöneticilerine dijital ortamda (online) gönderilmiş olup, araştırmaya gönüllü olarak katılan 21 farklı çiftlik yöneticisinden geri dönüş sağlanmıştır. Yöneticilerden elde edilen veriler içerik analizine tabi tutulmuş ve analiz sonucunda cevaplara ilişkin temalar belirlenmiştir. Bu kapsamda çiftliklerin kuruluş amaçlarını belirlemek için temalara yüzde - frekans analizi de uygulanmıştır. Ayrıca çiftliklerin, pandemi döneminde yaşadıkları sorunlar, bu sorunları fırsata çevirmek için uyguladıkları stratejiler ve pandemi sonrasına ilişkin vizyonları betimlenerek tablolar halinde verilmiştir. Katılımcıların verdiği cevaplardan Voyant Tools programı kullanılarak bir kelime bulutu da oluşturulmuştur.

\section{BULGULAR}

Bu bölümde araştırma kapsamında yer alan TaTuTa çiftliklerine ilişkin genel bilgilere, bu çiftliklerin pandemi öncesi ve sonrası faaliyetlerine, pandemi dönemindeki stratejilerine yönelik bulgulara yer verilmiştir. Tablo 1'de araştırma kapsamındaki ekolojik çiftliklerin genel özelliklerine ilişkin bilgiler yer almaktadır. Bu bağlamda ekolojik çiftliklerin varlığ 1500 'lü yıllara kadar dayanan köklü organizasyonlar olduğu görülmektedir. Faaliyet alanları $1625 \mathrm{~m}^{2}$ ile 800 dönüm arası değişmektedir. Çiftliklerin özelliklerinden ve kapasitelerinden kaynaklı olarak çalıştırdıkları ve ikamet eden kişi sayıları ile ağırladıkları ziyaretçi sayıları farklılık göstermektedir. Çalışmada bu çiftliklerin neredeyse tamamının ulusal ve uluslararası ziyaretçileri ağırladıkları tespit edilmiştir. Yöneticiler, çiftliğe gelen ziyaretçi sayılarının pandemi dönemine kadar artış trendi izlediğini belirtmişlerdir. Bu çiftliklerde sunulan hizmetler (konaklama, yiyecek içecek, kurs, etkinlik vb.) karşılığında genelde herhangi bir ücret alınmadı̆̆ı, ziyaretçilerin hizmet karşılığında genellikle emek ve bilgi desteği sağladıkları görülmüştür. Fakat bazı çiftliklerin, bazı hizmetler karşılığında kısmi ödemeler aldığı ve bazı çiftliklerinde belirli bir geceleme sayısından sonra ücret talep ettikleri tespit edilmiştir.

Tablo 2' de ekolojik TaTuTa çiftliklerinin kuruluş amaçlarına yönelik bilgilere yer verilmiştir. Bu kapsamda çiftliklerin kuruluş amaçları arasında ilk sırayı organik gıda üretiminin aldığı görülmektedir. Bununla birlikte çiftçilerin, sürdürülebilir doğal yaşamı korumak, doğal yaşamı desteklemek ve doğayla iç içe yaşamak, ekolojik hayatı sürdürmek, ekoturizm ve agroturizm faaliyetlerini yaygınlaştırmak gibi önemli amaçlarının olduğu saptanmıştır. 
Tablo 1. Ekolojik Çiftliklere İlişkin Genel Bilgiler

\begin{tabular}{|c|c|c|c|c|c|c|c|c|}
\hline \multirow[b]{2}{*}{ 光 } & \multirow[b]{2}{*}{ 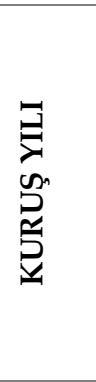 } & \multirow[b]{2}{*}{ 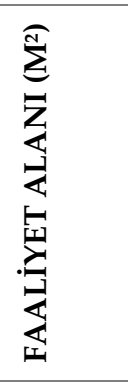 } & \multicolumn{5}{|c|}{ PANDEMI ÖNCESİ } & \\
\hline & & & 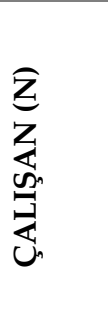 & 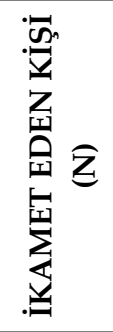 & 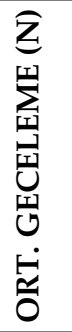 & 氙 & 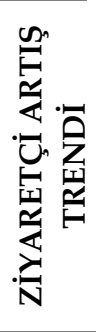 & $\begin{array}{c}\text { TATUTA ÇİFTLİKLERİNDE } \\
\text { HİZMET KARŞILIĞI }\end{array}$ \\
\hline 1 & 1500 & 500000 & 5 & 7 & 7 & ** & + & Emek ve Bilgi \\
\hline 2 & 2011 & 50000 & 4 & 4 & 5 & $* *$ & + & Emek ve Bilgi \\
\hline 3 & 2017 & 1625 & 9 & 1 & 5 & $* *$ & + & Emek ve Bilgi \\
\hline 4 & 2016 & 20000 & 15 & 5 & 8 & ** & + & Emek ve Bilgi \\
\hline 5 & 2019 & 4500 & 3 & 1 & 7 & * & + & Emek ve Bilgi \\
\hline 6 & 2019 & 3000 & NA & NA & 14 & $* *$ & + & Emek ve Bilgi \\
\hline 7 & 2007 & 800000 & 5 & NA & 7 & $* *$ & + & Emek ve Bilgi \\
\hline 8 & 2017 & 5000 & 5 & NA & 5 & $* *$ & + & Emek ve Bilgi \\
\hline 9 & 1993 & 10000 & 4 & NA & 20 & ** & + & $\begin{array}{c}\text { Konaklama ücreti dışında } \\
\text { Ekmek- Peynir Atölyesi } 140 \\
\text { TL/Kişi Sanat Atölyesi } \\
\text { 150TL/Kişi }\end{array}$ \\
\hline 10 & 2007 & 6500 & 28 & 4 & 14 & ** & + & Emek ve Bilgi \\
\hline 11 & 2012 & 6500 & 3 & NA & 5 & $* *$ & + & Emek ve Bilgi \\
\hline 12 & 2002 & 40000 & NA & 20 & 5 & $*$ & + & $\begin{array}{c}\text { Konaklama ücreti kişi başı } 70 \\
\text { TL için de sabah kahvaltısı } \\
\text { oluyor. Öğlen ve akşam } \\
\text { yemeklerinizde çiftlikte } \\
\text { yiyebiliyorlar }\end{array}$ \\
\hline 13 & 2016 & 5000 & 4 & 6 & 9 & $* *$ & + & Emek ve Bilgi \\
\hline 14 & 2004 & 30000 & 5 & NA & 8 & ** & + & Emek ve Bilgi \\
\hline 15 & 1500 & 400000 & 9 & NA & 9 & $* *$ & + & Emek ve Bilgi \\
\hline 16 & 1998 & 14000 & 5 & 7 & 24 & $* *$ & + & $\begin{array}{l}\text { Kursiyerler için iki günlük } \\
\text { kurslarımıza } 300 \text { TL gibi bir } \\
\text { ücret talep ediyoruz. Bu } \\
\text { ücrete konaklama ve bir } \\
\text { öğün yemek de dahildir. }\end{array}$ \\
\hline 17 & 2012 & 7000 & 8 & 6 & 3 & $* *$ & + & $\begin{array}{c}\text { 2-3 gün konaklamalar } \\
\text { ücretsiz }\end{array}$ \\
\hline 18 & 2012 & 5000 & & 1 & 20 & $* *$ & + & $\begin{array}{l}\text { Otel olarak hizmet verilen } \\
\text { bölümde ücret alınmaktadır }\end{array}$ \\
\hline 19 & 2015 & 5000 & 10 & NA & 2 & $* *$ & + & Emek ve Bilgi \\
\hline 20 & 2016 & 42000 & 6 & 8 & 20 & ** & + & 7- 30 gün arası ücretsiz \\
\hline 21 & 2002 & 40000 & NA & 4 & 7 & * & + & $\begin{array}{c}\text { 2-3 gün konaklamalar } \\
\text { ücretsiz }\end{array}$ \\
\hline
\end{tabular}

Açıklamalar: Ziyaretçi sayısı (Ulusal * Uluslararası **), Pandemi Öncesi Ziyaretçi Artış Trendi (Artış Halinde (+), Azalış Halinde (-)) NA: Not Application (Bilgi Yok) 
Tablo 2. Ekolojik Çiftliklerin Kuruluş Amaçları

\begin{tabular}{l|cc} 
TEMA & $\boldsymbol{N}$ & $\mathbf{\%}$ \\
\hline Organik gıda üretimi & 6 & 19,35 \\
Sürdürülebilir doğal yaşam & 3 & 9,68 \\
Doğayı korumak & 3 & 9,68 \\
Doğa Sevgisi doğal yaşamı desteklemek ve doğayla iç içe & 2 & 6,45 \\
yaşamak & & \\
Ekolojik hayatı sürdürmek & 2 & 6,45 \\
Eko turizm ve agro turizmi yaygınlaştırmak & 2 & 6,45 \\
Kendi kendine yeten yaşam alanları planlamak & 2 & 6,45 \\
Sağlıklı olmak & 2 & 6,45 \\
Tarım ve hayvancılığı geliştirmek & 1 & 3,23 \\
Hayalini gerçekleştirmek & 1 & 3,23 \\
Ekolojik tarımı gerçekleştirmek & 1 & 3,23 \\
Üretmek & 1 & 3,23 \\
Farkındalık oluşturmak & 1 & 3,23 \\
İnsan olmak & 1 & 3,23 \\
Adil tarım & 1 & 3,23 \\
Gıda ormanı konsepti & 1 & 3,23 \\
Hizmet etmek & 1 & 3,23 \\
\hline TOPLAM & 31 & $\mathbf{1 0 0 , 0 0}$
\end{tabular}

Tablo 3'te TaTuTa çiftliklerinin Covid-19 salgını döneminde yaşadığı krizlere ve krizleri fırsata çevirme stratejilerine yer verilmiştir. Tabloda bulunan yıldız $\left(^{*}\right)$ işaretinin sayısı krizlerin ve fırsatların sayısını ifade etmektedir. Buna göre, çiftliklerden bazılarının salgında sorun yaşamadıkları, bazılarının da bir veya daha fazla sorun yaşadıkları tespit edilmiştir. Bu kapsamda 2, 3, 5, 7, 8,13, 14, 17, 18, 19 ve 21 numaralı çiftlikler faaliyetlerini ve ziyaretçi kabulünü durdurduklarını belirtmişlerdir. Dolayısıyla bu çiftlerin krizi fırsata çeviremedikleri söylenebilir. 1 ve 15 numaralı çiftlikler yaşadıkları konaklama problemini ürün genişletme stratejisi ile (çiftlik çevresine kamp kurarak) çözmeye çalışmışlardır. 4 numaralı çiftlik yöneticisi, şarap satış hacminin düşmesi ve lojistik maliyetlerin artması sonucunda; ürün genişletme (ücretli tanıtım etkinlikleri), ürün çeşitlendirme (pekmez üretimi) ve pazar genişletme (pandemide şehir hayatından kaçma arzusu olan kişiler) şeklinde 3 farklı strateji ile krizi fırsata çevirmiştir. 6 numaralı çiftlik yöneticisi "pandemiden doğaya kaçış" sloganı (ürün tutundurma stratejisi) ile krizi fırsata çevirmeye çalışmıştır. 16 numaralı çiftlik yöneticisi turizm faaliyetlerinin durduğunu fakat tarım faaliyetlerinin devam ettiğini belirterek odaklanma stratejisi izlemiş ve sürdürülebilir tarım faaliyetlerine odaklanarak krizi fırsata çevirmiştir. 11 ve 12 numaralı çiftliklerin, yasaklar ve kısıtlamalardan dolayı kriz yaşadıkları ancak herhangi bir strateji uygulamadıkları için kazanım sağlayamadıkları saptanmıştır. 9 ve 10 numaralı çiftliklerin söz konusu dönemde faaliyetlerine kısmen ara verdikleri ancak stoklardaki ekolojik ürünleri daha yüksek fiyattan satarak (ürün tutundurma stratejisi) kazançlarını arttıkları belirlenmiştir. Yöneticilerin verdiği cevaplar kapsamında; risk alan ve riski yönetebilen çiftliklerin krizi fırsata çevirdiği, faaliyetlerini durduran işletmelerin ise krizden etkilendikleri saptanmıştır. Bu bilgi 20 numaralı çiftlik 
yöneticisinin "ziyaretçi kabul etmeyen işletmeler kriz yaşadı" ifadesiyle uyuşmaktadır. Ayrıca, 20 numaralı çiftlik yöneticisi risk alma stratejisi uygulayarak krizi fırsata çevirdiğini belirtmiştir.

Tablo 3. Covid-19 Salgın Döneminde Çiftliklerin Yaşadığı Krizler ve Krizleri Fırsata Çevirme Stratejileri

\begin{tabular}{|c|c|c|c|c|c|}
\hline ตี & 荇. & PROBLEM & 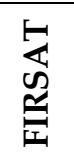 & STRATEJI & ÇÖZÜM \\
\hline 1 & * & Konaklama Problemi & $*$ & $\begin{array}{l}\text { Ürün } \\
\text { Genişletme }\end{array}$ & $\begin{array}{l}\text { Kamp Alanlarının } \\
\text { Kurulması }\end{array}$ \\
\hline \multirow{3}{*}{4} & \multirow{3}{*}{$*$} & \multirow{3}{*}{$\begin{array}{l}\text { Satış Hacmi Düştü (Şarap), } \\
\text { Lojistik Maliyeti Arttı }\end{array}$} & $\begin{array}{ll}* * \\
* \\
\end{array}$ & $\begin{array}{l}\text { Ürün } \\
\text { Genişletme }\end{array}$ & $\begin{array}{l}\text { Ücretli Tanitım Etkinlikleri } \\
\text { (Stoklara Yönelik) }\end{array}$ \\
\hline & & & & $\begin{array}{l}\text { Pazar } \\
\text { Genişletme }\end{array}$ & $\begin{array}{l}\text { Şehir Hayatından Uzakta } \\
\text { Kalmak İsteyen Kişiler }\end{array}$ \\
\hline & & & & $\begin{array}{l}\text { Ürün } \\
\text { Çeşitlendirme }\end{array}$ & Pekmez Yapımı \\
\hline 6 & ** & $\begin{array}{l}\text { Belirsizlik ve Risk Ortamı } \\
\text { Seyahat Kısıtlamaları }\end{array}$ & * & $\begin{array}{l}\text { Ürün } \\
\text { Tutundurma }\end{array}$ & $\begin{array}{l}\text { "Pandemiden Doğaya Kaçış" } \\
\text { sloganı }\end{array}$ \\
\hline 9 & * & $\begin{array}{l}\text { Ücretli Konuk veya Ziyaretçi } \\
\text { Gelmedi }\end{array}$ & $*$ & $\begin{array}{l}\text { Ürün } \\
\text { Tutundurma }\end{array}$ & $\begin{array}{l}\text { Ekolojik Ürünlere Talep } \\
\text { Arttı }\end{array}$ \\
\hline 10 & ** & $\begin{array}{l}\text { Faaliyetlere Bir Süre Ara } \\
\text { Verme, } \\
\text { Ziyaretçi Alımı Durdu }\end{array}$ & $*$ & $\begin{array}{l}\text { Ürün } \\
\text { Tutundurma }\end{array}$ & $\begin{array}{l}\text { Ekolojik Ürünlere Talep } \\
\text { Arttı }\end{array}$ \\
\hline 11 & $*$ & Seyahat Kısıtlamaları & & & \\
\hline 12 & * & Hafta Sonu Yasakları & & & \\
\hline 15 & * & $\begin{array}{l}\text { Konaklama Problemi (Sosyal } \\
\text { Mesafe, Covid } \\
\text { Tedbirlerinden Dolayı) }\end{array}$ & $*$ & $\begin{array}{l}\text { Ürün } \\
\text { Genişletme }\end{array}$ & $\begin{array}{l}\text { Kamp Alanlarının } \\
\text { Kurulması }\end{array}$ \\
\hline 16 & * & $\begin{array}{l}\text { Turizm Durdu, Tarım Devam } \\
\text { Etti }\end{array}$ & * & Odaklanma & Sürdürülebilir Tarım \\
\hline 20 & $*$ & $\begin{array}{l}\text { Ziyaretçi Kabul Etmeyen } \\
\text { İşletmeler Kriz Yaşadı }\end{array}$ & & Risk Alma & Ziyaretçi Kabul Etme \\
\hline
\end{tabular}

Tablo 4'te pandemi öncesi ve sonrası ekolojik çiftliklerin ve sektörün genel durumu hakkında yöneticilerin görüşlerine yer verilmiştir. Bu bağlamda genel olarak pandemi döneminde turistik ziyaretçi talebinin arttığı ancak kısıtlamalar nedeniyle artan taleplere istenilen düzeyde yanıt verilemediği belirlenmiştir. Yöneticiler, bu dönemde çiftliklere ilişkin farkındalığın arttığını ancak sinırlı sayıda ziyaretçi kabul edebildiklerini belirtmişlerdir. Bu dönemde ziyaretçi kabul eden işletmelerin krizi fırsata çevirdikleri, diğerlerinin ise sermayede küçülme ve ciddi gelir kayıpları yaşayarak krizi derinden hissettikleri saptanmıştır. Ziyaretçi sayısı azalan çiftliklerin ziyaretçilerin işgücünden mahrum kalması sonucunda işgücü maliyetlerinin ve işgücü yüklerinin arttığı da tespit edilmiştir. Yöneticiler, pandemi öncesi dönemde risk ve belirsizliğin düşük olduğunu fakat pandemi sonrası dönemde bu düzeyin oldukça arttığını belirtmiş̧lerdir.

Tablo 5'te ekolojik çiftlik yöneticilerinin, çiftlikleri için belirledikleri vizyonlarına ilişkin bilgilere yer verilmiştir. Buna göre yöneticilerin; sürdürülebilirlik, kendine yetebilmek, ilaçsız tarım, genç girişimciler, çiftçiyi geliştirmek, ekolojik yaşam, geleneksel üretimin kuşaklara aktarımı, lider olmak, başarmak ve değişimi takip etmek gibi sosyal sorumluluk temalı vizyonlara sahip 
oldukları saptanmıştır. Bu bağlamda yenilenebilir enerji, organik tarım, ekolojik yaşam, yaban hayatını koruma, genç girişimcileri destekleme gibi mesajlar içeren vizyon bildirgeleri ön plana çıkmıştır. Ayrıca bu vizyon bildirgelerinde geleceğe yönelik olumlu beklentiler de vurgulanmıştır.

Tablo 4. Covid-19 Pandemisinin Ekolojik Çiftliklerde Meydana Getirdiği Değişimler

\begin{tabular}{|c|c|c|}
\hline Sira & PANDEMI ÖNCESİ & PANDEMI SONRASI \\
\hline 1 & $\begin{array}{l}\text { Çiftlikler genel itibariyle yeterli gelir ve } \\
\text { sermayeye sahipti. }\end{array}$ & $\begin{array}{l}\text { Gelirde ciddi kayıplar, sermayede küçülme } \\
\text { meydana geldi. }\end{array}$ \\
\hline 2 & $\begin{array}{l}\text { Ekolojik çiftlikler yeterli düzeyde } \\
\text { ziyaretçi alımı yapmaktaydı. }\end{array}$ & $\begin{array}{l}\text { Ziyaretçi alan çiftliklerin ziyaretçi sayıları } \\
\text { kapasitelerine göre arttı, diğerleri kapattı. }\end{array}$ \\
\hline 3 & $\begin{array}{l}\text { Çiftlikler özel ilgi turizmi } \\
\text { kapsamındaydı. }\end{array}$ & $\begin{array}{l}\text { Herkes ekolojik çiftliklere ilgi duymaya } \\
\text { başladı. }\end{array}$ \\
\hline 4 & Belirsizlik az ve risk düşüktü. & Belirsizlik ve risk arttı. \\
\hline 5 & $\begin{array}{l}\text { Ziyaretçi sayısı yeteri düzeyde } \\
\text { olduğundan işgücü maliyetleri ve iş } \\
\text { yükü azdı. }\end{array}$ & $\begin{array}{l}\text { Ziyaretçi sayısı azaldığı için iş gücü } \\
\text { maliyetleri ve iş yükü arttı. }\end{array}$ \\
\hline 6 & Belirsizlik az ve risk düşüktü. & Belirsizlik ve risk arttı. \\
\hline 7 & Faaliyetler normaldi. & $\begin{array}{l}\text { Belirsizlikten dolayı faaliyetler kötü duruma } \\
\text { geldi. }\end{array}$ \\
\hline 8 & Yüksek talep ve yüksek arz vardı. & $\begin{array}{l}\text { Yüksek talep devam etti, arz düştü (ziyaretçi } \\
\text { kabul edilmedi). }\end{array}$ \\
\hline 9 & $\begin{array}{l}\text { Farklı konaklama türleri (klasik oteller) } \\
\text { sunan rakipler çoktu. }\end{array}$ & $\begin{array}{l}\text { Birçok rakip pasifize oldu ama seyahatler } \\
\text { kısıtlandığından pek bir avantajı olmadı. }\end{array}$ \\
\hline 10 & $\begin{array}{l}\text { Ekoçiftliklere karşı aşırı bir duyarlılık } \\
\text { ve bilinç yoktu. }\end{array}$ & $\begin{array}{l}\text { Ekoçiftliklere karşı farkındalık ve ihtiyaç } \\
\text { arttı, girişimcilerde çiftlik kurma isteği arttı. }\end{array}$ \\
\hline 11 & Farkındalık düşüktü. & Doğanın, organik tarımın değeri anlaşıldı. \\
\hline 12 & $\begin{array}{l}\text { Ekoçiftliklere ilgi düşüktü ama } \\
\text { kısıtlama yoktu }\end{array}$ & Ekoçiftliklere ilgi yüksek ama kısıtlama var. \\
\hline 13 & Ziyaretçi alımı ve üretim vardı. & $\begin{array}{l}\text { Ziyaretçi alımı durdu, üretim kısmen } \\
\text { devam ediyor. }\end{array}$ \\
\hline 14 & $\begin{array}{l}\text { Diğer konaklama tipine sahip } \\
\text { işletmelerle rekabet düzeyi düşüktü. }\end{array}$ & $\begin{array}{l}\text { Pandemiye uygun yapısıyla ekoçiftlikler } \\
\text { rekabet avantaji elde etti. }\end{array}$ \\
\hline 15 & Talep ve pazarlar açıktı. & $\begin{array}{l}\text { Hem ziyaretçi sayısında ciddi azalma oldu } \\
\text { hem de işlenmiş gıdalara pazar } \\
\text { bulunamadı. }\end{array}$ \\
\hline 16 & $\begin{array}{l}\text { Ekoçiftliklere talep yeterli düzeyde } \\
\text { değildi. }\end{array}$ & $\begin{array}{l}\text { Kapalı ve dar alanlara göre avantajlı } \\
\text { olduğu için ekoçiftliklerin pandemiden } \\
\text { dolayı ziyaretçi sayısı ve üretimi arttı. }\end{array}$ \\
\hline 17 & $\begin{array}{l}\text { Faaliyet etkili bir biçimde devam } \\
\text { ediyordu. }\end{array}$ & Pandemiyle faaliyetler durdu. \\
\hline 18 & Ekoçiftlikler gündem dişıydı. & Ekoçiftlikler gündeme geldi. \\
\hline 19 & Ziyaretçilerin üretime katkısı vardı. & $\begin{array}{l}\text { Ziyaretçiler azalınca iş gücü maliyetleri } \\
\text { arttı. }\end{array}$ \\
\hline 20 & $\begin{array}{l}\text { Ekoçiftlikler pazarlara yeni yeni nüfuz } \\
\text { ediyordu. }\end{array}$ & Çoğu çiftlik kapanmak zorunda kaldı. \\
\hline 21 & Ziyaretçi alımı serbestti. & Ziyaretçi alımı kısıtlı hale getirildi. \\
\hline
\end{tabular}


Tablo 5. Ekolojik Çiftlik Yöneticilerinin Vizyonları

\begin{tabular}{|c|c|c|}
\hline 竘 & TEMALAR & VİYYON \\
\hline 1 & $\begin{array}{l}\text { Sürdürülebilirlik (1), } \\
\text { Kendine Yetebilmek (1) }\end{array}$ & $\begin{array}{l}\text { Sürdürülebilirlik ve diş enerjiye/ gıdaya bağlılığı minimuma indirmekle doğru orantılı } \\
\text { bir üretim. }\end{array}$ \\
\hline 2 & İlaçsız Tarım (1) & Her şey normale döndüğünde ilaçsız tarım çalışmalarını ilerletmeyi düşünüyoruz. \\
\hline 3 & Genç Girişimciler (1) & $\begin{array}{l}\text { Daha çok bilgi ve farkındalık sahibi olan insanların, özellikle genç girişimcilerin ve } \\
\text { yatırımcıların bu yolda ilerlemesi ve istikrarlı şekilde yürümesi gerektiğini } \\
\text { düşünüyorum. }\end{array}$ \\
\hline 4 & $\begin{array}{l}\text { İlaçsız Tarım (2), } \\
\text { Kendine Yetebilmek (2) }\end{array}$ & $\begin{array}{l}\text { İlaçsız tarım ve yerli tohum kullanımında toplumsal bilinç kazanılması, bu amaçla yerli } \\
\text { üretime destek verilmesi yegâne amacımızdır. }\end{array}$ \\
\hline 5 & $\begin{array}{l}\text { Çiftçiyi Geliştirmek (1), } \\
\text { Ekolojik Yaşam (1) }\end{array}$ & $\begin{array}{l}\text { Çiftliği geliştirmek ve daha fazla gönüllü sayısına ulaşıp bu yaşam biçimini insanlara } \\
\text { empoze etme vizyonuna sahibim. }\end{array}$ \\
\hline 6 & $\begin{array}{l}\text { Geleneksel Üretimin } \\
\text { Kuşaklara Aktarımı (1) }\end{array}$ & $\begin{array}{l}\text { Doğal ortamı fazla tahrip etmeden belli kurallar çerçevesinde yapılanmaya gidilmesi, } \\
\text { eski yerleşim yerlerinde teşvik edilmesi, geleneksel üretim bilgilerinin geleceğe } \\
\text { aktarılması başlıca kurallar olmalıdır. }\end{array}$ \\
\hline 7 & Lider Olmak (1) & $\begin{array}{l}\text { İşlemiş ürünlerle birlikte } 60 \text { çeşit ürün üretiyoruz paketli veya açık, kuru veya yaş } \\
\text { olarak. Bu anlamda hepsini üreten ve işleyen olarak halen lideriz ve liderliğimizi } \\
\text { korumak istiyoruz. }\end{array}$ \\
\hline 8 & Başarmak (1) & $\begin{array}{l}\text { Gelecekte bu tür çiftliklerin daha başarılı olacağını ve daha yaygınlaşacağını } \\
\text { düşünüyorum. }\end{array}$ \\
\hline 9 & Ekolojik Yaşam (2) & $\begin{array}{l}\text { Pandemi biterse deneyimlemek ve yerleşmek için ekolojik alanları tercih edenler } \\
\text { bulunmaktadır. }\end{array}$ \\
\hline 10 & Ekolojik Yaşam (3) & $\begin{array}{l}\text { Pandemi döneminin bitmesinden itibaren ekolojik hayata katılan insan sayısının } \\
\text { giderek artacağını düşünüyorum. }\end{array}$ \\
\hline 11 & Sürdürülebilirlik (2) & $\begin{array}{l}\text { Kendimizi geliştirerek ekolojik okur yazarlığımızı daha derinleştirerek, ekosistemden } \\
\text { ilham alan ve uyumlu teknolojileri kullanarak, yaban hayatını, yabani bitkilerinin } \\
\text { sürdürülebilirliğini sağlamak. }\end{array}$ \\
\hline 12 & Ekolojik Yaşam (4) & $\begin{array}{l}\text { Büyük kentlerde doğadan ve üretimden kopmak zorunda kalmış insanlar mutlaka } \\
\text { tekrar yüzünü doğaya ve üretime dönecektir. }\end{array}$ \\
\hline 13 & Ekolojik Yaşam (5) & Ekolojik yaşamın ve ekolojik yaşam alışkanlığının insanlara yayılmasıdır. \\
\hline 14 & Genç Girişimciler (2) & $\begin{array}{l}\text { Daha genç kişilerin girişimlerinin özellikle son beş yılda hızlandığını ve bu } \\
\text { hızlanmanın artarak devam edeceğini görüyoruz. }\end{array}$ \\
\hline 15 & $\begin{array}{l}\text { Kendine Yetebilmek (3), } \\
\text { Değişimi Takip Etmek (1), } \\
\text { Ekolojik Yaşam (6) }\end{array}$ & $\begin{array}{l}\text { Çiftlik topluluğu (aile) olarak iklimlerdeki değişimi görebiliyor ve farkındaysak gelecek } \\
\text { için de yaptığımız işlere devam etmeyi, dışarıya bağımlı olmayı en aza indirgemeyi } \\
\text { sürdürmeliyiz. Bunu yaşam biçimi olarak görmek başlıca vizyonumuz. }\end{array}$ \\
\hline 16 & $\begin{array}{l}\text { Ekolojik Yaşam (7), } \\
\text { Gelişim (1), } \\
\text { Sürdürülebilirlik (3) }\end{array}$ & $\begin{array}{l}\text { Canlı türlerinin birbirlerine fayda sağladığı, paylaşımın daha çok olduğu sistemler de } \\
\text { daha güçlüdür, dirençlidir. Böyle sistemler doğal bir dengeye ulaşırlar ve bir ahenk } \\
\text { içinde yaşamlarını sürdürürler. Bu ahenk sağlandığında yaşam kolaylaşır, zenginleşir. } \\
\text { Doğa bizim yaşam kaynağımızdır ve eğer öğreticimiz olursa, çözümü de görebiliriz. } \\
\text { Çiftliğimizdeki yaşam gittikçe kolaylaşıyor, güzelleşiyor. Sürdürülebilir yaşam } \\
\text { mümkün, bu yaşam tarzına artan sayıda insan dahil olacağını düşünüyorum. }\end{array}$ \\
\hline 17 & $\begin{array}{l}\text { Gelişim (2), } \\
\text { Değişimi Takip Etmek (2) }\end{array}$ & Bu çiftlikler yaygınlaşacak ve yeni bir eko turizm anlayışı olacaktır. \\
\hline 18 & $\begin{array}{l}\text { Gelişim (3), } \\
\text { Lider Olmak (2) }\end{array}$ & Ekolojik çiftlikler gelecekte en fazla tercih edilen lokasyonlar olacaktır. \\
\hline 19 & $\begin{array}{l}\text { Sürdürülebilirlik (4), } \\
\text { Çevresel Olumlu Etkiler } \\
\text { (1) }\end{array}$ & $\begin{array}{l}\text { Ayrıca her ne kadar şu anda en önemli gündem Covid-19 olsa da iklim değişikliği } \\
\text { nedeniyle gıda üretiminde yaşanan kayılplar ve buna bağlı olarak kırsalda zaten düşük } \\
\text { olan sosyal ve ekonomik refahın daha da düşmesi söz konusu. Her iki konuda da hem } \\
\text { kırsaldaki doğa dostu geleneksel uygulamaların devamllığı, hem de iklim } \\
\text { değişikliğinin etkilerinin azaltılması için doğayla uyumlu üretimin garantisi olan küçük } \\
\text { aile çiftçilerinin devamlılı̆̆ ve desteklenmesi çok önemlidir. }\end{array}$ \\
\hline 20 & $\begin{array}{l}\text { Çevresel Olumlu Etkiler } \\
\text { (2), } \\
\text { Gelişim (4), } \\
\text { Ekolojik Yaşam (8) }\end{array}$ & $\begin{array}{l}\text { Biz tarım turizminin gelişmesini istiyoruz o yüzden çalışmalarımız bu sistemin doğayı } \\
\text { koruma şartıyla daha geniş bir alana duyurulmasını sağlamak ve bu alanda daha } \\
\text { yaşanılır daha sağlıklı bir dünya bırakmak. }\end{array}$ \\
\hline 21 & $\begin{array}{l}\text { Gelişim (5) } \\
\text { Ekolojik Yaşam (9) }\end{array}$ & $\begin{array}{l}\text { Arazimin birinin çevresini ağaçlandırdım sonraki aşamada gıda ormanı ve peyzaj, } \\
\text { ağaçtan evler yaptırmayı planlıorum. }\end{array}$ \\
\hline 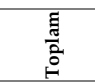 & \multicolumn{2}{|c|}{$\begin{array}{l}\text { Ekolojik Yaşam (8), Gelissim (5), Sürdürülebilirlik (4), Kendine Yetebilmek (3), Çevresel Olumlu Etkiler (2), Lider } \\
\text { Olmak (2), Değişimi Takip Etmek (2), Genç Girişimciler (2), İlaçsız Tarı (2), Başarmak (1) }\end{array}$} \\
\hline
\end{tabular}


Şekil 1'de, tablo 5'te bulunan yönetici vizyonlarına yönelik temaların yüzdelik dağılımlarına yer verilmiştir. Şekilde bu temalar arasında en çok ekolojik yaşam $(n=8 ; \% 26)$, gelişim $(n=5, \% 16)$, sürdürülebilirlik ( $n=4, \% 13)$ ve kendine yetebilme $(n=3, \% 10)$ temaları dikkat çekmektedir.

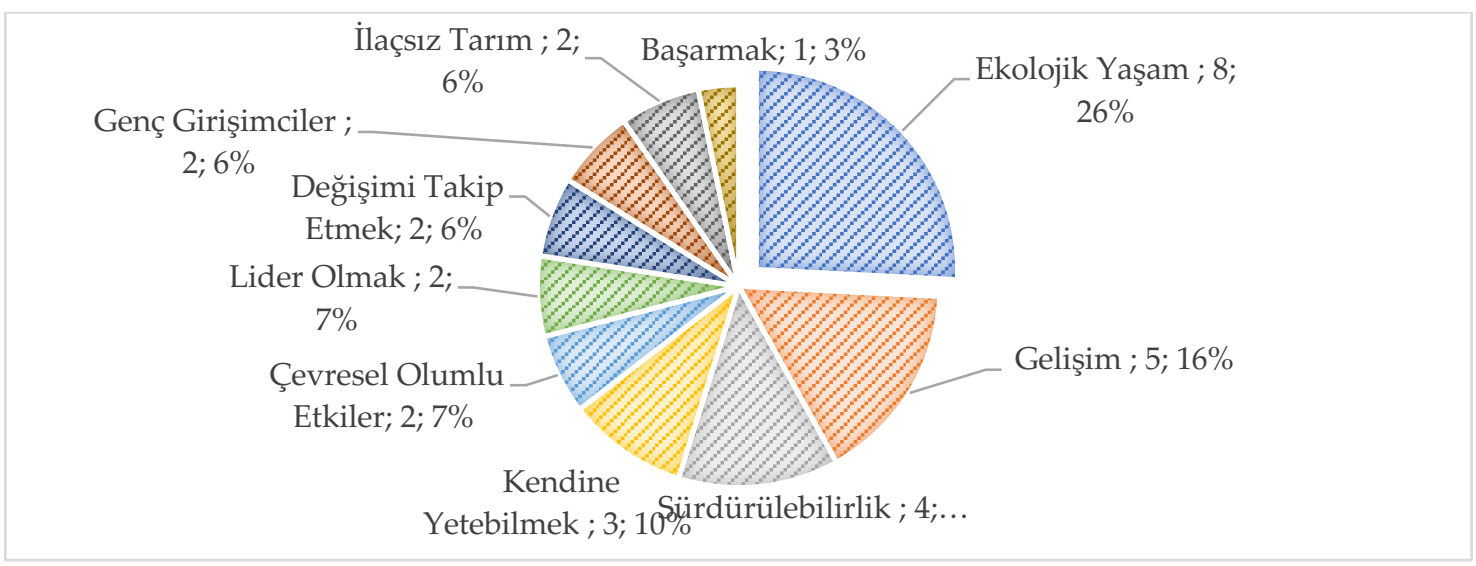

Şekil 1. Yöneticilerin Vizyonlarına İlişkin Temaların Yüzdelik Dağılımı

Şekil 2'de katılımcı yöneticilerin verdikleri cevaplara ilişkin en sık kullanılan kelimeleri tespit edebilmek için bir kelime bulutu oluşturulmuştur. Kelime bulutunda, kelimeler sıklık düzeyi arttıkça daha merkezi konuma ve daha büyük puntolarla yerleştirilmektedir. Dolayısıyla bu analizde en merkezi konumda olan ve en büyük puntolarla yazılan kelimeler en önemli temalar olarak değerlendirilmektedir. Buna göre, konaklama, ilaçsız tarım, ekolojik, çiftlik, gönüllü, doğal, tarım, yaşam, sürdürülebilirlik ve kendine yetebilmek gibi kelimelerin ön plana çıktığ 1 görülmektedir. Dolayısıyla, bu kelimelerin genellikle ekolojik tarımın faydalarına işaret ettiği söylenebilir.

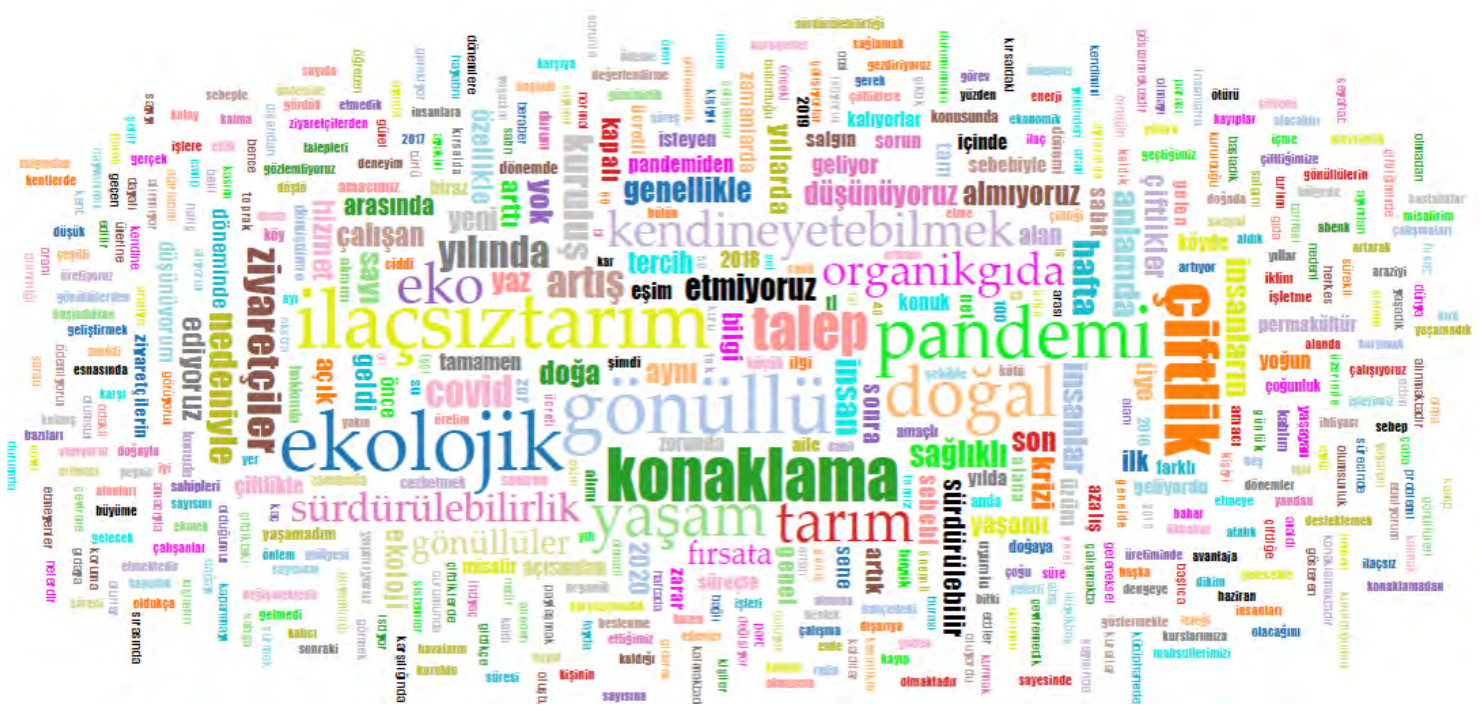

Şekil 2. Yöneticilerin Cevaplarına İlişkin Kelime Bulutu

\section{TARTIŞMA, SONUÇ ve ÖNERİLER}

Günümüzde yaşanan pandeminin birçok sektörü olumsuz etkilediği, insanların faaliyet alanlarının ve alışkanlıklarının da değişmesine neden olduğu görülmektedir. Bu kapsamda 
kalabalık gruplar halinde büyük ölçekli turizm işletmelerinde kitle turizm etkinliklerini tercih eden insanların, pandemiyle birlikte turizm anlayışlarının da değiştiğini söylemek mümkündür. Dolayısıyla taleplerin, doğal ortamda ekolojik tarım faaliyetlerinin gerçekleştirildiği, tarım turzmi potansiyeli olan çiftliklere kaydığı görülmektedir. Çalışmada ekolojik çiftliklerin, söz konusu pandeminin yarattığı krizi fırsata dönüştürebilme kabiliyetlerini ve bu amaçla uyguladıkları stratejileri ortaya koymak amaçlanmıştır. Buna göre, örneklem kapsamında incelenen 21 TaTuTa çiftliğinin pandemi nedeniyle birtakım sorunlar yaşadığı saptanmıştır. Ancak, bu çiftliklerden 11 tanesi kriz ortamında risk almaktan kaçınarak herhangi bir strateji geliştirmemiş, tarım turizmi faaliyetlerini ve ziyaretçi kabulünü durdurmuştur. Ayrıca bu çiftlikler ziyaretçilerin iş gücünden de mahrum kalmış ve tarımsal faaliyetlerdeki iş gücü maliyetleri de artmıştır. Pandemi krizini fırsata dönüştürmek isteyen ve risk alan 10 çiftlik ise bu süreçte tarım turizmi faaliyetlerini ve ziyaretçi alımlarını sürdürmüştür. Bununla birlikte bu çiftlikler; ürün genişletme, ürün farklılaştırma, tutundurma ve odaklanma gibi stratejiler geliştirerek krizi fırsata çevirmeyi başarmıştır. Araştırmada, pandemi döneminde ekolojik çiftliklere yönelik farkındalığın ve çiftliklere olan talebin arttığı belirlenmiştir.

Çalışmada çiftliklerin genelde ulusal ve uluslararası ziyaretçileri ağırladıkları, ziyaretçi sayılarının pandemi öncesi önemli düzeyde arttı̆̆ tespit edilmiştir. Fakat pandemi döneminde ekolojik çiftliklere olan ilginin artmasına rağmen, kısıtlamalar nedeniyle çiftliklerin faaliyetlerini verimli bir şekilde gerçekleştiremediği belirlenmiştir. Çiftliklerin ziyaretçilere konaklama, yiyecek içecek, kurs, etkinlik gibi hizmetler sunduğu, bu hizmetler karşılığında çiftlik yönetiminin genelde herhangi bir ücret talep etmediği bunun yerine ziyaretçilerden emek ve bilgi desteği aldığı saptanmıştır. Ekolojik yaşam teması başta olmak üzere kendine yetebilmek, ilaçsız tarım, genç girişimciler, çiftçiyi geliştirmek, geleneksel üretimin kuşaklara aktarımı gibi hedefler çiftlik yöneticilerinin vizyonları olarak belirlenmiştir.

TaTuTa çiftliklerinin kuruluşunda, organik gıda üretimi, sürdürülebilir doğal yaşam ve doğanın korunmasının amaçlandığı saptanmıştır. Çalışmanın bu sonucu, Zengin ve Savgın (2016), Şimşek (2016), Şekerli (2018)'nin çalışmaları ile örtüşmektedir. Bu çalışamalarda da TaTuTa çiftliklerinin kuruluş amaçlarına ve yararlarına yönelik çıktılar ekolojik yaşamı destekleme eksenindedir. Dolayısıyla sürdürülebilir çevre anlayışı ile ekolojiyi korumayı amaçlayan TaTuTa çiftliklerinin ekonomik, toplumsal ve çevresel kazanımlarının sağlanabilmesi için çeşitli öneriler getirilmesi çalışmayı önemli kılmaktadır.

Bu çerçevede öncelikle kitle turizminin çevre üzerindeki baskısı azaltılarak olumsuz etkilerinin minimize edilmesi amacıyla TaTuTa çiftliklerinin sayılarının arttırılmasının bir zorunluluk olduğu düşünülmektedir. Nitekim bu çiftliklerin sayısının arttırılması amacıyla devlet teşviklerinin yanı sıra yerel yönetimler ile sivil toplum kuruluşlarının maddi ve manevi desteği önem arz etmektedir. Bununla beraber çiftliklerde üretilen ürün çeşitliliğine gidilmesinin farklı yaş grubunda bulunan olası ziyaretçiler için çekici olacağı düşünülmektedir. Ayrıca ürünlerin yetişme sürecinin ziyaretçiler tarafından gözlemlenebilmesi amacıyla kısa sürede yetişebilen ürünlerin tercih edilmesi önem arz etmektedir. Çünkü ziyaretçilerin tarlaya ektikleri ürünlerin büyüdüğünü ve yetiştiğini görmesi, bu turizm faaliyetini ziyaretçiler açısından daha cazip hale getirebilir. Böylelikle turistlerin çiftliklerde daha uzun süre gecelemesi sağlanabilir. Bu durum çiftliklerde uzun süreli iş gücü imkanı da yaratabilir. Ucuz işgücünün, ürünlerin elde edilme maliyetlerini düşürmesiyle tüketicilere daha ucuz ve organik tarım ürünü sunulabilir.

Pandemi krizi ile ekolojik yaşam, sürdürülebilirlik, tarım, turizm ve doğa gibi kavramların öneminin arttığı anlaşılmıştır. Dolayısıyla tarım turizmi kapsamında, TaTuTa çiftliklerinin amacına ve faaliyetlerine ilişkin etkin tanıtımların yapılması çiftliklerin gelişimi için önemlidir. Çünkü bu çiftliklerin artması ve gelişmesi özellikle ülkemizde çeşitli problemler içerisinde yer 
alan tarım ile hayvancığa yeni bir çığır açarak, yenilenmesine, gelişmesine büyük katkılar sağlayabilir.

Çalışma, Türkiye'de TaTuTa projesi kapsamında faaliyet gösteren ekolojik çiftlikler ile sınırlandırılmıştır. Bununla birlikte araştırma amacıyla sınırlı sayıda çiftlik yöneticisi görüşmeyi kabul etmiştir. Bu durum araştırmanın kısıtı olarak ifade edilebilir. Çalışmanın, proje kapsamında yer almayan Türkiye'de faaliyet gösteren ekolojik çiftlikler üzerine uygulanması araştırmacılara önerilmektedir. Bu yolla daha geniş örneklem ile araştırmacıların farklı sonuçlara ulaşabilmesi mümkündür. $\mathrm{Bu}$ doğrultuda çalışmanın araştırmacılara yön vereceği düşünülmektedir.

\section{KAYNAKÇA}

Ahmadova, S. ve Akova, O. (2016). Türkiye'de Organik Ekoturizm Çiftlikleri Üzerine Bir Araştırma, Karabük Üniversitesi Sosyal Bilimler Enstitüsü Dergisi, 6(1): 15-29.

Civelek, M. (2013). Sürdürülebilirlik Kapsamında Agro-Turizm ve Kırsal Kalkınma İlişkisi: Muğla Yöresindeki Tatuta Çiftliklerinin Agro-Turizm Potansiyeli Yönünden Değerlendirilmesi, Yayınlanmamış Yüksek Lisans Tezi, Muğla Sıtkı Koçman Üniversitesi, Muğla.

Civelek, M., Dalgın, T. ve Çeken, H. (2013). Agro-Turizm ve Sürdürülebilirlik İlişkisi: Muğla Yöresindeki TaTuTa Çiftliklerinde Bir Araştırma, Journal of Tourism and Gastronomy Studies, 1(3): $22-32$.

Çeken, H. (2004). Küreselleşme Eğilimlerinin Uluslararası Turizm Hareketlerine Etkisi ve Türkiye, Muğla Üniversitesi SBE Dergisi, 12: 1-11.

Çıkın, A., Çeken, H. ve Uçar, M. (2009). Turizmin Tarım Sektörüne Etkisi, Agro-Turizm ve Ekonomik Sonuçları, Tarım Ekonomisi Dergisi, 15(1): 1-8.

Deniz, S., Özden, O., Akgün, O. ve Yıldırım, H. M. (2018). Agro Turizm Tesislerinin Gastronomi Faaliyetleri Açısında Değerlendirilmesi: Çanakkale Örneği, Journal of Tourism and Gastronomy Studies, 6(3): 364-378.

Gökalp, D. D. ve Yazgan, M. E. (2013). Kırsal Peyzaj Planlamada Agroturizm ve Agriturizm. KMÜ Sosyal ve Ekonomik Araştırmalar Dergisi, 15(24): 25-29.

Gündüz, S. (2004). Ankara İli Kalecik İlçesindeki Tarımsal Turizme Uygun Alanların Saptanması ve Tarımsal Turizm Modelinin Oluşturulması Üzerine Bir Araştırma. Yayınlanmamış Doktora Tezi, Ankara Üniversitesi, Ankara.

Gönülsüz, Ş. (2015). Ekolojik Çiftliklerde Tarım Turizmi ve Tecrübe Takası, Yaşam Kültürü Dergisi, 24-27.

Karakaya, A. G. (2017). Dalaman ve Fethiye Yöresindeki Hayvancilık İşletmelerinin Agroturizm Potansiyeli, Yayınlanmamış Yüksek Lisans Tezi, Adnan Menderes Üniversitesi, Aydın.

Mahaliyanaarachchi, R. (2015). Agri Tourism Farm Stay. Published By: Department of Agri Business Management Faculty of Agricultural Sciences Sabaragamuwa University of Sri Lanka.

Mason, P. (2004). Tourism Impacts Planning and Management. Heinemann: Oxford, Elsevier Butterworth.

Mcintosh, A. J. and Bonnemann, S. M. (2006). Willing Workers on Organic Farms (WWOOF): The Alternative Farm Stay Experience? Journal of Sustainable Tourism, 14(1): 82-99. 
Selvi, M. S. ve Demirer, D. (2012). Ekolojik Tatil Çiftliklerinin Tatuta Projesi Deneyimine İlişkin Örnek Olay İncelemesi, Anatolia: Turizm Araştırmaları Dergisi, 23(2): 187-202.

Sharpley, R. and Sharpley, J. (1997). Rural Tourism: An Introduction. London: Thomson Business Press, London.

Şekerli, S. (2018). Tarım Turizmi (Tatuta) Projesi Kapsamında Faaliyet Gösteren Ekolojik Çiftliklerde Bir Araştırma: İzmir İli Örneği, Yayınlanmamış Yüksek Lisans Tezi, İzmir Kâtip Çelebi Üniversitesi, İzmir.

Şimşek, O. (2016). Alternatif Bir Ekolojik Yaşam Modeli: Tatuta (Ekolojik Çiftliklerde Tarım Turizmi ve Gönüllü Bilgi, Tecrübe Takası) Projesi. Yayınlanmamış Yüksek Lisans Tezi, Cumhuriyet Üniversitesi, Sivas.

Tatuta/WWOOF Türkiye 2021. https://wwoofturkey.org/ (Erişim Tarihi: 25.03.2021)

Vanderweele, T., Chen, Y., Long, K., Kim, E., Trudel-Fitzgerald, C. and Kubzansky, L. (2020). Positive Epidemiology? Epidemiology, 2(31): 189-192.

Yamamotoa, D. and Engelstedb, A. K. (2014). World Wide Opportunities on Organic Farms (WWOOF) in the United States: Locations and Motivations of Volunteer Tourism Host Farms, Journal of Sustainable Tourism, 22(6): 964-980.

Yang, Z., Cai, J. and Susuza, R. (2010). Agro-Tourism Enterprises Form of Multi-Functional Urban Agriculture for Peri-Urban Development in China, Habitat International 34: 374-385.

Yılmaz, H. (2008). Turizm Çeşitlendirilmesi Kapsamında Eko Turizm Ürünü Olarak Tatil Çiftlikleri: Türkiye'deki Tatil Çiftliklerine Yönelik Swot Analizi. Yayınlanmamış Doktora Tezi, Afyon Kocatepe Üniversitesi, Afyon.

Zengin, E. ve Savgın, C. (2016). Türkiye Çiftlik Turizminin Neresinde? Balıkesir Üniversitesi Sosyal Bilimler Enstitüsü Dergisi, 19(35): 475-493. 